authority, adopted that date in my Aldermen of London (p. 59). Wilson was at the time sheriff of London and resident in the city, and his death may well have been known in the house of commons on the same day on which it occurred, but Smyth is not always accurate to the day, and the true date of Wilson's death may have been a day or two earlier, but in any case between February 16 and 19 inclusive. His successor in the shrievalty, John Dethicke, was elected on the same day (19 February) to which Smyth assigns his death, as we know from the official minute in the Guildhall records. ${ }^{9}$ That the election of his successor should have taken place on the day of his death, though quite possible and not without precedent, ${ }^{10}$ seems hardly likely; but at any rate, if the assumed date of death (19 February) be correct, there would be nothing more strange in the house of commons deciding to elect a successor to him as a member of the council of state on the following day, at the same time that other vacancies were to be filled, than in the election of a new sheriff in his place on the actual day of his death. Wilson was certainly dead before the election of the five additional members on 20 February, and therefore the number of the council of state remained forty-one, ${ }^{11}$ as in the previous and subsequent years.

AJfRED B. BEAYEN.

\title{
Pitt and the Campaign of 1793 in Flanders.
}

Arona the Pitt Papers in the Public Record Office (nos. 102 and 162) are some letters that passed between Pitt and Sir James Murray on the campaign in Flanders of 1793 . Unfortunately the correspondence is far from complete; but even so it throws light on the operations in Flunders and on the expedition to Toulon, and is therefore worth publishing.

In the first days of the year 1798, when war with France seemed imminent, ministers decided to send Sir James Murray, Bt., to the Prussian headquarters at Frankfort-on-the-Main to concert measures in case of a rupture. ${ }^{1}$ He remained there some six weeks, and was then transferred to the headquarters of the dake of York in Holland. He conferred with ministers in London about the beginning of April, and then returned to lay before the duke important instructions drafted on the 16th, and to act as correspondent and adviser. ${ }^{2}$ At that time the Duke had with him in Flanders only 4200 British Infantry and 2800 cavalry; but 13,000 Hanoverians (in British pay) were expected, and a corps of

- Common Hall Book, ii, fo. 307b.

10 There are one or two cases on record of lord mayors being elected in the afternoon of the same day on which their predecessors had died in the morning.

"Mrs. Everett Green, in ignorance of the fact that Wilson was dead before the new conncil took office, includes his name in the list throughout the gear, but of course with blanks in the attendance columns.

1 Dropmoro Papers, ii. 369.

= War Office Despatch of April 18. 
8000 Hessians mas being hired at Cassel. Apart from these, 17,000 Dutch troops were available. The prince of Coburg with the Austrian army had recaptured the Low Countries after his decisive victory at Neerwinden; and the defection of Dumouriez on April 5 left the French armies at Lille and Valenciennes for a time leaderless. The successes gained by the Vendeans also imperilled the Republic. The first letter that I have discovered is dated just a week after the downfall of the Girondins, which heralded a series of risings in Normandy, at Lyons, and in the South of France. The letters are too long to give in fall; but I have retained the important parts in extenso, also the whole of Pitt's letter of July 19 to Murray. Pitt's letters to Murray, except that of July 19, are missing. All the following letters, except the last but one, are from Sir James Murray to Pitt.

[Précis.]

Private.

Estreus, June 9, 1798.

Murray has received Pitt's letter of May 30; 20,000 Bohemian grenadiers are expected by Coburg as reinforcement. In six weeks all his army would have arrived, and would then consist of 70,000 Austrians, 28,000 British, Hanoverians, and Hessians, 17,000 Dutch, and 8000 Prussians. Their actions must depend on those of the French and on the state of the siege of Valenciennes. Their numbers were scarcely adequate to the duties before them. ${ }^{3}$ If, however, a stronghold on the French coast could be taken, the case would be different.

[Précis.]

Private.

Estreux, June 25, 1793.

Before August they would have an overwhelming force in the field. He regards the success of an attack on Dunkirk as "infallible." Is it to be held for the Emperor, or as a British conquest? Possibly the Hessians might be withdrawn without harm to the cause; but it is most desirable to take the frontier fortresses, especially Quesnoy and Maubeuge, and the line of the Lys, and thus isolate Lille.

At present there were 9100 men fewer at hand than was expected; the first division of Hessians had been sent to Mainz; it was not known when the second division would arrive. This absence of the Hessians would leave under the Duke of York only a body of 16,000 or 17,000 men, far too small a number. Could three regiments of infantry be sent? They might soon be withdrawn, if wanted elsewhere.

'I conceive from your letter that you have no idea of sending a small body to the assistance of the royalists in France, which I confess would appear to me to be e measure of considerable risk.'

'Private and confidential.

Estreux, July 2, 1793.

'Dear Sir,-I have thrown out lately in two letters, one addressed to you and another to Mr. Dundss, some loose thoughts upon the operations

3 This is a specimen of the timidity which ruined the campaign. The French were then demoralised and inferior in number. Even in July Jomini assigns to them only 100,000 men in the whole of Belgium and in Limburg. At present they can bave had scarcely more than 70,000 men.

- For George III's approval of the attack on Dunkirk see Dremyore Papers, ii. 387. 
of the campaign; there were, however, points in both to which I hope that you have been good enough to attend. I sball now state to you with a little more precision $m y$ ideas upon the subject, after further reflection and some little change in the prospect of the siege. I am the more disposed to this as I understand from Lord Rochester that the Court of Vienna has met your wishes in regard to future political arrangements.

' The successes of the royalists and the distracted state of the country having rendered it, as it appears, impossible for the enemy to collect a formidable army in this quarter, the present appeared to be an opportunity too favourable to be neglected of making solid and essential conquests. The most important of all, perhaps, would have been that of Douay; bat the strength of that place and the extent of the oircumvallation render that plan entirely incompatible with the enterprise against Dunkirk, as the one would leave too little time to undertake these sieges separately and the other render it hazardous to carry them on together. It appeared that if we had got possession of Valenciennes as soon as many people expected-that is, about the 10th of this month-the armies might have remained united until Quesnoy should be reduced, or perhaps even Maubeuge, the siege of which might have been undertaken at the same time. I am sorry to say that the siege does not appear likely at present to take that turn.'

Murray then asks whether ministers think it advisable to besiege Dunkirk with 40,000 men (that is, with the troops in British pay, and 15,000 or 16,000 Austrians), and 'whether you will find any difficulty in furnishing the necussary artillery for the siege from England.'

[Précis.]

Estreux, July 4, 1793.

Colonel Mack, who had the entire control of everything, had been replaced by Prince Hohenlohe, who was his inferior in ability. Things moved slowly and his [Murray's] advice was slighted at headquarters.

[Précis]

Estreax, July 9, 1793.

Murray acknowledges Pitt's letter and says the prolongation of the siege of Valenciennes has vitiated their plans. It cannot now be taken till the 7th or 8th of next month. He hopes then to take Dunkirk and St. Venant (a place of great importance). Then finter quarters will be secure, covered by the river on the left. The Duke of York objected to the Hessians being detached from his command.

- Private and confidential.

Estreux, July 9, 1799.

'Dear Sir,-Upon further reflection I shall add a few words to my "private" letter of this day. It is for you to determine upon the relative importance of the objects in the attainment of which you propose to employ the Hessians and of those which I have proposed. I am myself anxious for the general success of the war. I do not wish to have 40,000 men employed where 30,000 may suffice. If therefore it should appear that the objects which are in view in Flanders can be accomplished with the smaller force, if additional exertion or even a degree of risk were to be the consequence, provided the purpose were worthy of it, I should think they might be submitted to. Much will depend 
upon the state of the enemy; perhaps it will be found that every object but St. Venent can be accomplished without the Hessians. These are only loose ideas, but I cannot well, without being master of all the circumstances, give a more decided opinion. I am in hopes that you will collect from them enough to assist you in forming yours.'

[Précis]

Private.

Estrenx, July 12, 1793.

Murray conld not publicly allude to the proposed separation of the Hessians, it having been named only in private correspondence. Prince Hohenlohe's plan is not to undertake anything in Flanders until Mainz is taken; he deems an enterprise on the seacoast to be particularly hazardons. 'The executive arrangement is that, since a previous engagement renders the siege of Dunkirk unavoidable, the best situation for the covering army will be between Menin and Ypres. . . . You mention in your letter of the 5th, that you wish Dunkirk to be taken at all events by the end of August.'

This, he adds, could hardly be, because of the siege of Valenciennes and the possibility of an attack by Custine's army. He gathers, too, that Pitt would not detach the Hessians at the expense of the fall of Maubeuge and Quesnoy-'objects of vast importance.'-News had arrived from Paris of a royalist viotory in the West.

Pitt replied as follows to Murray's letters :-

' (Private and confidential.)

Downing Street, July 19, 1793.

'Sir James Murray, Bt.

- Dear Sir,-I have had the pleasure of receiving your different letters of the 4th, 9th, and 12th, and enter perfectly into the reason which naturally makes it desirable that what you mention to me confidentially should remain secret. Such a mode of commanication may be very useful on many points which at least at first could not be officially discussed.

'You will perceive from Mr. Dundas's despatch that the plan of operations which you have proposed is fully approved. Our wish, if possible, to have the separate use of the Hessians is mentioned only in general terms. My anxiety on that subject proceeds on the notion that if they can be spared without materially cramping your operations, they may enable us to make an impression in other quarters which may perhaps tend materially to shorten the duration of the war. With the same view I have been considering whether we may not be able to propose to you to part with the three regiments of the Line, sending in exchange an additional corps of cavalry which I should conceive as part of any Army of Observation would be greatly more useful to you than infantry. If this could be managed, I think, by exertions, we might be able, after sending in the autumn all that we want for active service in the West Indies, to collect at home and for Gibraltar three or four thousand British troops ; and if they can be joined by the Hessians, and by further corps of the troops of Wirtemberg (which we are trying to engage) to form on the whole a force which might be sent (before the season is too far advanced) to the Mediterranean. It might there be employed to the greatest advantage, considering our naval superiority there, in some. 
material enterprize in that quarter, in conjunction with the forces of Sardinia and Naples, and probably some Austrians from the Emperor's Italian dominions. The force so collected might on the whole be formidable enough to gain some solid advantage, and would probably be able to act with effect at a later period than is practicable on this side of France.

'I am very much impressed with the idea, which you have more than once mentioned, of bringing a respectable force to act on the same point. But with such a confederacy as now exists this idea does not exclude acting on that principle against many points at the same time. What I now mention seems to give a fair chance of doing something material in the south, and if we can distress the enemy on more sides than one while their internal distraction continues it seems hardly possible that they can long oppose any effectual resistance.

'I state this quite for your private consideration, and in order to put you fully in possession of my general view. At the same time I by no means wish to aim at this object at the expense of retarding or endengering your operations, which I consider as more essential than any others. It seems to me to be possible, in case of your attacking and beating Custine, that you may be able to spare the force in question without hazard. It is also possible, if the Austrian reinforcements should turn out to be larger than had been stated, that instead of $15,000,20$ or 22,000 Austrians might be joined to the army under the duke of York's command. Or, if neither of them is the case at first, it may be [i.e. by] good fortune happen that your successes may be rapid enough to make one or other of those arrangements practicable, early enough in the autumn to leave time for effecting the plan I have pointed out. Besides these alternatives, we may also hope that the Prussians may at last be induced to act with more vigour, the effect of which would probably soon put the prince of Cobourg more at his ease. I am sure at all events you will turn the subject in your mind with the view of suggesting whatever may be practicable; and I shall be much obliged to you for letting me know all that occurs to you upon it.

' You will see by the papers which Mr. Dundas sends you that, with a view to the siege of Dunkirk etc., we are able to supply most of the articles necessary, but are uncertain with respect to the number of artillery. I should add also that the duke of Richmond seems to consider the number of 246 (if it can be obtained) in addition to what you now have, as very inadequate. It may be useful to state on what grounds the calculation is made. I should also be glad to know to what extent you wish the aid of seamen, either in addition to the artillery or, in case a sufficient number of the latter cannot be furnished; we will endeavour to ascertain in what other respects naval co-operation can be rendered useful.

I am, etc., IV. Pitt.

Private and confid'.

Estreux, July 23, 1793.

[Murray acknowledges receipt of Pitt's letter.]

' There is little reason to hope that the present campaign will put an end to the war, independent of some great internal revolution upon which 
we have no right to calculate; but it is very desirable that it should not go beyond the next. The re-establishment of monarchy in France is most desirable. Even temporary peace can hardly, I think, be expected from the present wild and desperate system of government, at least without relinquishment of the conquests which have been made. The most likely means of accomplishing a change appears to be the possession of Paris, which J should not conceive to be at all impracticable to acquire in the course of the next campaign, if the great efforts of the Powers were directed to that object.'

He adds that for this end the main army of allies should be increased from 110,000 to 180,000 men. Leaving 30,000 to cover Flanders, two armies should advance ints France, one by St. Quentin, the other by Havre and the Seine (Normandy being royalist).

He says the duke of York mainly agrees with him. For the present the entire defeat of Custine's army is not to be depended on. Dunkirk might be taken with 30,000 men, and Bergues also; but the garrisons must be left there. The great object is the blockade of Lille. "To maintain this and to secure the line from Dunkirk to Maubeuge will certainly require a very considerable force. I rather think that a amall diminution will not be likely to affect us in this point, but if it should appear to be otherwise, an object of such importance onght certainly not to be risked.'

He doubta the wisdom of sending a force to Southern France, and in any case he hopes Pitt will leave them the 2nd brigade [of Hessians] because infantry is more wanted than cavalry. 'You must not take away the brigade of the Line on any account.' $\mathrm{He}$ would like 800 seamen to serve the artillery. Colonel Moncrieff should have the direction of the siege.- It is very unlikely that the officer the duke of Richmond mentions should know anything about the matter at all. . . There is no calculating what we may suffer by pedantry and ignorance.'

As bas been stated above, George III was very desirous of acquiring Dunkirk in order to render the war popalar in England. ${ }^{5}$ The decision was a disastrous one. For after the capture of Condé, Valenciennes, and Quesnoy, when an advance in force towards Paris might have led to great results, the allies separated, the duke of York proceeding to besiege Dunkirk with a covering force of Austrians and Dutch, while the main forces of the Imperialists scattered for other siege operations. The results are well known; and the defeats of the allies at and near Dunkirk on 5-8 September justified the protests of Hohenlohe against that enterprise. In view of the lack of British gunboats at Dunkirk the request of Pitt to know what naval co-operation would be required is noteworthy. Still more so is the entire ignorance of the allies as to the great forces which France was mustering.

\section{J. Holland Rose.}

- The War Office despatch of 16 April to Murray lags stress on this consideration. 